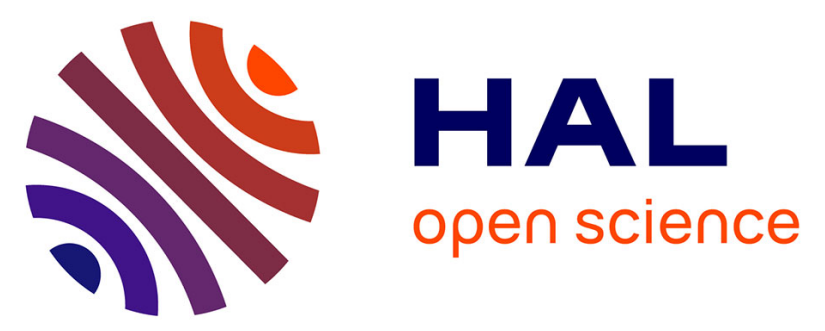

\title{
The adaptative nature of neoliberalism at the local scale: fifteen years of city improvement districts in Cape Town and Johannesburg
}

Sophie Didier, Marianne Morange, Elisabeth Peyroux

\section{- To cite this version:}

Sophie Didier, Marianne Morange, Elisabeth Peyroux. The adaptative nature of neoliberalism at the local scale: fifteen years of city improvement districts in Cape Town and Johannesburg. Antipode, 2013, 45 (1), http://onlinelibrary.wiley.com/doi/10.1111/j.1467-8330.2012.00987.x/abstract. halshs01471853

\section{HAL Id: halshs-01471853 \\ https://shs.hal.science/halshs-01471853}

Submitted on 20 Feb 2017

HAL is a multi-disciplinary open access archive for the deposit and dissemination of scientific research documents, whether they are published or not. The documents may come from teaching and research institutions in France or abroad, or from public or private research centers.
L'archive ouverte pluridisciplinaire HAL, est destinée au dépôt et à la diffusion de documents scientifiques de niveau recherche, publiés ou non, émanant des établissements d'enseignement et de recherche français ou étrangers, des laboratoires publics ou privés.

\section{(1) (1) $\$$}

Distributed under a Creative Commons Attribution - NonCommercial - NoDerivatives 44.0 


\title{
THE ADAPTATIVE NATURE OF NEOLIBERALISM AT THE LOCAL SCALE: FIFTEEN YEARS OF CITY IMPROVEMENT DISTRICTS IN CAPE TOWN AND JOHANNESBURG
}

\begin{abstract}
By unravelling the adoption and adaptation of the North American Business Improvement District model in South African cities, this paper considers the way neoliberal principles are making their way in the post-apartheid context. Drawing on a comparative approach of BIDs in Johannesburg and Cape Town, we analyze the tensions and conflicts surrounding their implementation and unpack the resilience of this model. As unexpected as this resilience might be in such a context, i.e. far away from the heartland of neoliberalism, we argue that this resilience is linked to the permeability of the local contexts and to the plasticity of the model itself at the city and neighbourhood levels, reflecting a capacity to adapt to inherited regulatory frameworks, patterns of territorial development and embedded socio-political alliances of the local terrains, as well as an ability to accommodate postapartheid issues through the crafting of what we refer to as "local Third Ways".
\end{abstract}

Keywords: neoliberalism; urban regeneration; urban policy mobilities; Business Improvement Districts ; South Africa ; Johannesburg ; Cape Town.

\section{BIDs, NEOLIBERAL URBANISATION AND SOUTH AFRICAN CITIES}

Since the 1990s, the North American Business Improvement District (BID) model has been adopted in South African cities under the name of City Improvement District (CID), to support urban regeneration strategies in a context of changing and declining urban economies. As area-based PublicPrivate Partnerships (PPPs), BIDs are self-taxing schemes financing additional services in order to promote the attractiveness of a district and enhance its commercial and business activities.

BIDs are often described as part of the debates on the reconfiguration of urban governance, in both North America and Europe. The literature calls on various theoretical perspectives, ranging from "new regionalism" (Wolf 2006) and the network governance theory (Morçöl and Zimmermann 2006), to political economy (Ward 2006; Eick 2008), governmentality and surveillance studies (Marquardt and Füller 2008; Lippert 2009). Many of these analyses are rooted in the debate on "neoliberal urbanisation", where BIDs appear emblematic of the multi-faceted process of national and local institutional change, as generated by the adoption of neoliberal principles and practices at the urban scale, such as PPPs, New Public Management and entrepreneurialism (Harvey 1989; Brenner and Theodore 2002b). Through their circulation via international professional networks (Hoyt 2006; Didier et al. 2009; Cook 2008, McCann and Ward 2010), BIDs are also emblematic of "the transnational repertoire of neoliberal strategies" (Brenner et al. 2010a: 214) and illustrate the dissemination of neoliberalisation projects within changing institutional regimes and new interlocality policy relays (Brenner et al. 2010b). Considered emblematic of neoliberal policies, BIDs have generated criticism due to their profit-oriented conception of redevelopment through the creation of commodified spaces of elite consumption, the intensified surveillance of public spaces and collateral exclusionary processes (Mitchell 2003; Töpfer et al. 2007).

In South Africa, researchers analyse CIDs as tools of local urban management, security policing (Berg 2004) or local economic development (LED) (Rogerson 1996). Other authors describe CIDs as part of the neoliberal or entrepreneurial debates, focusing on their governance structure (Dubresson 2008), the declension of the model in a single city (Murray 2008; Peyroux 2008), or the policy transfer process in terms of "best practices" (Didier et al. 2009). While CIDs are gradually conceptualised within the broader process of neoliberalisation, their stability and their ability to find "a stable ground" in South Africa has been questioned, notably in central Cape Town (Miraftab 2007), as CIDs are challenged by social movements. Following up on Miraftab's paper, we consider the local anchorage of CIDs and 
Didier S., Morange M., Peyroux E., 2013, “The Adaptative Nature of Neoliberalism at the Local Scale: Fifteen Years of City Improvement Districts in Cape Town and Johannesburg”, Antipode, 45(1), pp. 121-139.

wish to demonstrate that the local tension around CIDs has actually led over the past decade to adaptations of the original model, exemplifying the creative capacity of neoliberalism to overcome internal contradictions as well as local resistance in both Johannesburg and Cape Town.

This article therefore empirically documents theoretical literature about the practices of neoliberalism on the city scale (Brenner and Theodore 2002), answering the call for a more nuanced place-based assessment of neoliberalisation as a process (Larner 2003, Leitner et al. 2007). It does so by enriching this perspective with a focus on the urban and intra-urban scales. The same neoliberal principles that guide CIDs operating in the same national context have indeed resulted in distinct regulations due to the local political structures. Distinctive forms of local governance as well as micro-local territorial adaptations to neoliberalisation have taken place. Beyond another empirical account of the geographical uneven development of neoliberalisation, and beyond the actual South African case study, we underline the importance of taking into account the intra-urban scale to decipher the differentiation of neoliberalisation. It also allows us to explore the neoliberalisation of policies and practices from a bottom-up perspective.

This article also builds on the recent refinement of theories on neoliberalisation (Brenner et al. 2010 and b) and contributes to the debate on the "variegation of neoliberalisation", as the "systemic production of geo-institutional differentiation" (Brenner et al. 2010a: 184 and 211), by suggesting research tracks on the structural creative processes driving the adaptation of South African CIDs. Two context-dependent processes of "variegation" can be distinguished: the permeability of local contexts influencing the capacity of CIDs to take root and transform so as to better fit the local political, institutional and economic milieus; the plasticity of CIDs, i.e. their capacity to thwart local political resistance by accommodating post-apartheid concerns and defusing political contestation. We believe these coupled characteristics might be worth considering in accounts of neoliberalisation elsewhere.

To carry out this comparative analysis of the reception and diffusion of CIDs in Cape Town and Johannesburg, we relied on a qualitative methodology and conducted around 60 in-depths interviews with representatives of local governments, CID management structures, development agencies and NGOs between 2004 and 2009. They were complemented by a critical analysis of the material published by CID management bodies as well as press articles reflecting local reception and political debates around CIDs.

The first section of the paper questions the permeability of Johannesburg and Cape Town as regards CID reception, by retracing their development, linking them with post-apartheid restructuring and contextualizing them in the neoliberalisation processes at national and local levels. It illustrates the weight of the local terrains in the diffusion and adaptation of CIDs at the city and neighbourhood levels. Here, we emphasise the role of the private sector acting as "active progenitor" of neoliberalizing experimentations (Brenner et al. 2010a: 196). In doing so, we move the focus away from political reforms at the city scale, and bring a different perspective to the considerable body of literature on neoliberalisation in South Africai.

The second section questions the plasticity of CIDs, by analyzing the controversies surrounding them. CIDs have proliferated and evolved in parallel with the efforts of metropolitan authorities to tailor post-apartheid redistributive policies at city level. South African cities with their legacy of political struggle, social, and most especially racial inequalities, and the post-apartheid expectations of a middle-income country, constitute a unique terrain far from the heartland of neoliberalism to unravel the dialectical nature of this adaptation, a structural process that fosters the resilience of the model. Despite their exclusionary effects and a tradition of struggle for integration and social justice in South African cities, CIDs have generated little contestation compared to other forms identified as core neoliberalisation processes. We argue that it demonstrates resilience linked to the emergence of "local Third Ways", i.e. the capacity of the local PPP coalition to accommodate critiques through charitybased "flanking mechanisms" (in Cape Town) or the capacity of some private actors to address social issues pertaining to low income inner-city residential neighbourhoods (in Johannesburg).

\section{CIDS AND LOCAL PERMEABILITIES TO NEOLIBERALISATION}


Didier S., Morange M., Peyroux E., 2013, “The Adaptative Nature of Neoliberalism at the Local Scale: Fifteen Years of City Improvement Districts in Cape Town and Johannesburg”, Antipode, 45(1), pp. 121-139.

\section{CIDs as a Pragmatic and Privately-Led Way of Achieving Urban Regeneration}

The implementation of CIDs answered a shared concern within the private and public spheres over economic and business decline in city centres and the related fall in property values and tax base. As ad-hoc and micro-local solutions, CIDs were indeed introduced by the private sector in the early 1990s. Yet the CID chronology differs between Cape Town and Johannesburg, illustrating the difference in scope and nature of urban decline over three decades as well as the adaptability of the model.

The CBDs of both cities suffered from the rise of suburban economic nodes from the 1970s onward, the relocation of department stores in the 1980s and capital flight in the 1990s. In Johannesburg, office vacancies increased, rents decreased, and property values sank, leading to a "redlining" of these areas by the banks. Municipal rates followed while large companies relocated to the northern suburbs, as did the Johannesburg Stock Exchange (Beavon 2004, Tomlinson 1999). In Cape Town, capital flight to the southern and northern suburbs (Claremont and Century City) was only partial, with a less important decline in property values (City of Cape Town 1989), while the city centre suffered from the development of the nearby Waterfront in the late 1980s, dragging an important part of the economic activity away from the CBD.

Johannesburg's inner city also faced urgent housing needs arising from now predominantly black residential populations. It experienced an early process of residential "greying": in the mid-1980s, Indian and Coloured, and later on African people looking for an alternative accommodation to the townships started to move into the once White-only inner city (the CBD, Berea, Hillbrow, Yeoville...) (Morris 1999). The "White flight" accelerated in the 1990s (Guillaume 2001). Living conditions in over-crowded and squatted buildings deteriorated mostly because of a lack of maintenance by property owners (Beavon 2004). These changes took place in a context of high levels of fear of crime linked to escalating crime rates. In Cape Town the inner city is smaller in terms of residential weight - with around 55000 inhabitants (SSA 2001), as opposed to at least 200000 in Johannesburg's high density inner city (City of Johannesburg 2004) - and with less derelict high-rise residential buildings, squatting opportunities remained limited. The inner city has always been "mostly White" and its fringes, on the slope of Table Mountain, accommodate upper middle and upper classes, e.g. Gardens, Tamboerskloof or Higgovale (Le Fleur 2005).

In Johannesburg, there was an early and strong perception among (the then mostly White) members of the private sector of a loss of control over the environment, and they introduced CIDs so as to make up for the perceived failure of public authorities to deliver appropriate standards of service, safety services in particular. The Central Johannesburg Partnership (CJP) was established in 1992 by a prominent figure of the local business community, first as a trilateral partnership between businesses, the local authority and "the community" (represented by various Community-Based Organisations). After the local elections of 1995, the CJP concentrated on the sole representation of inner city business and became a private, non-profit company financed by major inner city businesses (banks, insurance and large property companies). Its active lobbying was instrumental in the adoption of the CID model: the CJP organised study tours of US BIDs with regional and city officers in the mid-1990s, lobbied for the establishment of the first CID in the CBD as early as 1993, on an experimental and voluntary basis (not compulsory for all the property owners), and subsequently participated in the drafting of the CID legislation (Peyroux 2008). Following the success of this pilot project which focused on "crime and grime", several CIDs were established in the CBD, especially in small 'precincts' where they could easily get the buy-in of as many property owners as necessary. The capacity of the CJP to rally a growing number of property owners played a role in the success of the model, as well as the advantage for the municipality of delegating some of the day-to-day management issues to CIDs.

CIDs also entered Cape Town's CBD through property owner mobilisation. The first CID, the Central City Improvement District (CCID), was set up in 2000 by the Cape Town Partnership (CTP), a nonprofit structure dominated by local business interests resulting from the joined initiative of the South African Property Owners Association (SAPOA) and the Regional Chamber of Commerce and 
Didier S., Morange M., Peyroux E., 2013, “The Adaptative Nature of Neoliberalism at the Local Scale: Fifteen Years of City Improvement Districts in Cape Town and Johannesburg”, Antipode, 45(1), pp. 121-139.

Industry. . It also sought inspiration in internationally acclaimed "best practice" models and participated in the writing of the municipal bylaw on CIDs. In a context where urban decline was less advanced and urban regeneration already on the public agenda (St George's Mall was revamped in the late 1980s for instance), it is the security component of the BID model that first appealed to property owners. As in Johannesburg, the original focus was on "crime and grime", and CIDs entered Cape Town as tools of security policing (Berg 2004). Only at a later stage did the model evolve toward a broader regeneration agenda, when the CTP became a bilateral partnership between the City and the business owners of the CBD. Within this coalition, the strength of the private sector is best exemplified by the capacity of the CCID influential property owners ${ }^{\mathrm{ii}}$ to force the municipality into a contractually binding "Service Level Agreement", whereby financial penalties are enforced onto the City if it fails to deliver a pre-defined level of service so as to ensure that CID levies only complement public service (Morange and Didier 2009).

\section{CIDs and Neoliberalising Local Policies}

During this period of time (in the mid-1990s), South Africa notoriously embraced neoliberal measures in the field of macro-economic policies. The is illustrated by the shift from the Redistribution and Development Programme (RDP), a social development policy implemented after the first democratic election $^{\text {iii }}$, to the Growth, Employment and Redistribution strategy (GEAR) in 1996 (Peet 2002). The moderation of initial ANC radicalism and the move towards neoliberal economic principles ${ }^{\text {iv }}$ have been explained by the nature of the post-apartheid transition, characterised as a negotiated "elitepacted compromise" (Bond 2006: 141), as well as the influence of international organisations (Marais 2001). Yet, since the 2005 launch of the Accelerated and Shared Growth Initiative for South Africa (AsgiSA), economists have been discussing extensively whether South Africa is shifting away from neoliberal policies towards the achievement of the "Developmental State". They have pondered the contradictory ideological strains coexisting within the major African National Congress (ANC)-run spheres of government (Fine et al. 2010). But this initiative portrays similar objectives to that of the RDP and GEAR; it proposes measures to ensure that growth is accelerated and shared through infrastructural programmes, skills development, education initiatives and the expansion of the social safety net (Du Toit 2006). Alternative terms and analytical frameworks to neoliberalisation are also used, such as "mixed-economy", "post-apartheid distributional regime" (Seekings and Nattrass 2005), or "Third Way" policies, with varying interpretations among the scholars (Green-Pedersen et al. 2001; Michie and Padayachee 2001; de Beus and Koelble 2001), as is the case in Europe (Giddens 2000; Fuller and Geddes 2008). These different conceptualisations show that it is difficult to identify a coherent set of policies across sectors, particularly across economic and social sectors.

At the local level, concerns over efficiency, fiscal discipline, growth and competitiveness became dominant in the mid-1990s in a context of growing unemployment, high levels of governmental debts and budget deficits. While the creation of metropolitan authorities (Unicities) ${ }^{\mathrm{vi}}$, at the end of the 1990s, was designed to combat the inherited imbalances within metropolitan areas in terms of service delivery (Cameron 2000; Pieterse 2003 and 2004), their mandate, from the start, also encompassed Local Economic Development (LED). Earlier LED interventions based on place marketing and property-led regeneration had been pioneered since the late 1980s, for instance in Johannesburg (Rogerson 2003), but in the mid-1990s the role of the city as a growth machine was emphasised, reflecting an entrepreneurial turn at the local level. In parallel, local governments were affected by the classic processes of devolution, outsourcing, privatisation and corporatisation of public services provisions. This shift was enforced at the cost of central tensions in both cities, exemplifying the "dual agenda of economic growth and development" (Parnell and Robinson 2006: 341) and well-illustrated by the succession of policy documents in both cities:

- in Johannesburg, the controversial "iGoli 2002" plan, implemented in a context of major financial crisis by the ANC-run local and provincial governments, drew on New Public Management principles such as cost-recovery (Parnell et al. 2002, Beall et al. 2002), and allowed for the corporatisation of urban services while a few other services were privatised (Mabin 2007). "iGoli 2002" was followed 
Didier S., Morange M., Peyroux E., 2013, “The Adaptative Nature of Neoliberalism at the Local Scale: Fifteen Years of City Improvement Districts in Cape Town and Johannesburg”, Antipode, 45(1), pp. 121-139.

by a participatory and multi-stakeholder "visioning process" aimed at defining the City Development Strategy (CDS) ("iGoli 2010"), a form of strategic planning advocated by the World Bank. This exercise, completed under the name "Joburg 2030 Strategy", clearly moved towards economic development (Lipietz 2008): it promoted an outward-oriented economy, in order to achieve a vision of Johannesburg as "a World Class African city" (Rogerson 2004) with an economic vitality that would have trickle-down effects to the benefit of the social sphere. The 2005 Human Development Strategy (HDS), as an addition to the Joburg 2030 Strategy, acknowledged the need to "accommodate a human development perspective and address conditions such as poverty, inequality and social exclusion on a city-scale" (City of Johannesburg 2005: 2). The "gaps and weaknesses" of the Joburg 2030 Strategy and the need to "revisit" the strategy (Ibid.: 4) by taking into account housing, environment and community development, are thus acknowledged in the Johannesburg Growth and Development Strategy of 2006 (Parnell and Robinson 2006), as well as the 2007 Inner City Regeneration Charter.

- in Cape Town, no city-wide and long-term vision expressing such a clear turn emerged. The lack of City Development Strategy has been attributed to the instability of the local politics and rivalries between the African National Congress (ANC) (the dominant political party) and its contender, the Democratic Alliance (DA) (the liberal and main opposition party). This instability is said to encourage "the prevalence of 'ad-hoc-ism' and 'short-termism': "few political leaders and parties are able to see further than the next five-year term of office"vii. As a result, the "shift from the role of provider to the role of ensurer" (Pieterse 2002: 19, quoting McLachlan 2000, chairperson of the Unicity Commission) was gradual and less controversial. There was a sprinkling of neoliberal principles in the recommendations of the Unicity Commission which were drafted in collaboration with private consultants and the private sector in 2000 , and these principles were visible in the outsourcing and corporatisation of some services, in the fact that PPPs were called upon, and in the enforcement of New Public Management. Neoliberalisation can also be traced in the Going Global, Working local 1999 City Report, after both the DA and the ANC embraced the "World Class marketing" agenda aimed at attracting FDI and tourists consistently and without any "shift in policy orientation by any of the major political parties" (McDonald and Smith 2004: 1467). It accounts for the focus on "growth centres" (City of Cape Town 2009: 30), the "support to business clusters" (IDP and 2009 Central City Development Strategy) and the creation of an Urban Development Zone in the CBD (a tax free perimeter) (City of Cape Town 2005: 9), as well as a systematic resort to CIDs.

Most of these policy documents rely on the idea of the "trickle-down effect" of growth as a mechanism to reduce poverty and inequality, and subsequently achieve a global redistributive agenda: "economic growth, led by investment, is one of the best ways that we can improve the lives of all the people (...), especially the poor" (H. Zille, CCDS 2009, quoting an OECD report on Cape Town). Yet the actual mechanisms are not specified, and the ways and means of redistribution are seldom demonstrated (even more so in the case of CIDs). Interpreting these policy documents as a proof of the profound neoliberalisation of South African cities, also needs to be nuanced: they appear more as an assemblage of pragmatic and opportunistic policies than the implementation of a coherent long-term strategy. With regards to CIDs, local authorities essentially caught up with privately initiated processes by drafting post-hoc legislation: the first municipal bylaw on CIDs in Cape Town was passed in 1999, drawing on the 1997 provincial legislation of Johannesburg, leading to similarities in these regulatory frameworks ${ }^{\text {viii. }}$.

\section{Local Variations and the Adaptability of the CID Model}

Once secured in city centres (early 2000s), CIDs spread to the entire metropolitan space and diversified following the economic and social logics of micro-local regeneration initiatives or LED. In Johannesburg, there are currently about 20 CIDs (legislated or "voluntary", "informal" or "special projects", i.e. not legislated or required to fulfil the same legal standards as legislated CIDs). CIDs were developed in the economic nodes of affluent northern suburbs (e.g. Rosebank, Sandton, Illovo and Randburg), where business and property owners are concerned over vacancy rates, image issues and growing competition between economic nodes, hence the focus on branding and marketing 
(Peyroux 2008). In the low income and densely populated neighbourhoods of the inner city, e.g. Yeoville, Berea and Hillbrow, housing companies resort to CIDs to address the degradation of public environment and infrastructure, and support the management of decaying housing stocks since 2005. In Cape Town, there are currently 17 CIDs: in "predominantly residential areas" of the inner city (Green Point, Sea Point and Oranjekloof) where they spatially complemented the CCID in 2001; in suburban business nodes, either declining (Bellville) or thriving (Claremont); in industrial areas and tertiary parks; in residential neighbourhoods affected by social problems (Woodstock). According to the City's 2001 vision: "all major centres [are meant] to have CIDs in place by 2005" (City of Cape Town 2001: 18). Non-legislated schemes are forbidden and all CIDs focus on service delivery, with a major security component.

Moreover, both Cities have been addressing requests from suburban communities to set up "residential CIDs" in neighbourhoods that are not declining, and where the residents' major concern lies in the perceived post-apartheid increase in property crime. This South African specificity has led to integrate the CID concept within the broader national policy framework of community policing initiatives (Bénit-Gbaffou et al., 2009) so as to avoid their diversion and drift toward vigilantism. In Cape Town, after a ban on "community CIDs" through the rewriting of the bylaw in 2004 (for details see Morange and Didier 2008 and 2009), the City has recently reinstated them in Groote Schuur and Rondebosch (Roumet 2010), provided CID boards create close partnerships with the police. In 2008, the City of Johannesburg also approved residential CIDs, albeit under the same conditions as in Cape Town ${ }^{\text {ix: }}$ this ambiguous and changing regulation illustrates the will of the local authorities to accommodate the flexibility of the model.

In terms of governance, while most of the CIDs of Johannesburg's inner city are managed by the CJP, public involvement is important: the City has integrated CIDs into the 2004 Inner City Regeneration Strategy Business Plan and uses the additional provision of services, as well as marketing and branding activities to develop special precincts (the cultural precinct of Newtown, the Fashion District, the heritage tourism district of Constitution Hill, or Ellis Park, a sports precinct developed for the 2010 World Cup). The Johannesburg Development Agency (JDA), an agency of the City created in 2001 to support area-based regeneration and economic development in the inner city, co-finances some CIDs. Its board of directors includes members of organised labour, the business community, community leaders and elected officials. In Cape Town, CIDs are mentioned in planning documents, but in an allusive manner, as "special rating areas" (City of Cape Town 2001). In the inner city, the PPP structure is based on a strong connection between the CTP and the City via a centralised structure of governance: the CTP is largely funded by the City - it received a R6 million grant in 2009, i.e. $70 \%$ of its budget (CTP 2009) - and its role has evolved to include a broader mission to brand the "rejuvenation" of its centre. The CTP collaborated with the City to draft the Central City Development Strategy and is currently co-managing the CCID that spatially identifies with the destiny of the CBD (Boraine 2009). The other CIDs are privately run, CID boards occasionally partnering with the City, as was the case to co-finance ambitious infrastructure development projects in Claremont.

\section{PLASTICITY: CONTESTING CIDS AND THE SEARCH FOR "LOCAL THIRD WAYS”}

Beyond these micro local adaptations, the attempts to address the tensions between growth, competitiveness and social concerns at metropolitan level, led to the gradual crafting of "local Third Ways"., These changes reflect both the national injunction towards a more redistributive policy, and local attempts to defuse political contestation, albeit with major differences between the two cities: the introduction of charity-style flanking mechanisms within the CCID linked to an evolution of the functioning of the PPP in Cape Town; and the pioneering of a residential CID, in the inner city suburbs of Johannesburg, by private actors building on contemporary discourses about social capital and the relevance of local social relations for LED (Forrest 2001).

Defusing contestation

True to its legacy of political struggle, South Africa has been witnessing strong attacks from unions 
Didier S., Morange M., Peyroux E., 2013, “The Adaptative Nature of Neoliberalism at the Local Scale: Fifteen Years of City Improvement Districts in Cape Town and Johannesburg”, Antipode, 45(1), pp. 121-139.

and poor communities against neoliberalisation. They mostly focus on the shift of macro-economic policies and the reform of public service delivery (Emery 2006). In Cape Town, the principle of cost recovery is challenged by a coalition of Community-Based Organisations (the Anti-Eviction Campaign) calling for free access to water and electricity, and opposing the eviction of defaulters as well as water cut-offs in the black and coloured townships (Plancq-Tournadre 2006, Oldfield and Stokke 2007). In Johannesburg, the iGoli 2002 plan crystallises opposition from the Anti-Privatisation Forum composed of municipal unions, leftist intellectuals and popular movements (Parnell and Robinson 2006), which opposes the reform of the water sector.

As far as CIDs are concerned, the repertoire of commoditisation and privatisation is seldom employed. Contesters frame their criticism in terms of "previously disadvantage communities" and their discourses are rooted in the memory of apartheid rather than in a direct criticism of neoliberalisation. Few questions are raised about the ring-fencing of local taxes (the CID levy cannot be spent outside of the CID perimeter) or the one-property-one-vote system of CIDs while the emergence of shadowgovernments is only criticised by scholars (Bénit et al. 2008, Murray 2008). Depending on the local context, attacks focus on gentrification or on rights-related issues linked to the broader "social cleansing" of public space, e.g. the restrictions on street trading, deemed incompatible with modern shop-window city centres. It became a prominent concern with the 2010 World Cup.

In Cape Town, due to the specificities of the CBD, contestation focuses on the assault on street children, homeless people and sex workers and points towards exclusionary processes based on racial prejudices. In other contexts, these are the target of opponents to neoliberal urban policies (Mitchell 2003; Töpfer et al. 2007) but here the post-apartheid rhetoric prevails: the provocative image of the 'volkstaat', a political concept that refers to the dream of a separate and self-ruled Afrikaner state, was used in Cape Town to describe affluent communities resorting to CIDs, in an extreme statement made by a local journalist ${ }^{\mathrm{xi}}$. In Johannesburg, the Gauteng Hawkers Association, which represents predominantly black informal traders, denounced the relocation of street traders into formal markets, arguing that it "was based purely on prejudice against subsistence black retailing in an area that is being 'insulated' by CJP to be the way it was 15 years ago"xii, a reference to the ban on trading in central areas for Africans until the late 1980s siii. Community-based organisations also oppose the eviction of poor tenants and squatters (occupying shacks and derelict buildings) from the city centre as part of the municipal Better Buildings Programme and the Inner City Strategy that promote the upgrading and conversion of "bad buildings" (COHRE 2005: 68). This is indirectly connected to the CIDs as some of the housing and property companies involved in CIDs benefit from this programme.

As stated by Miraftab (2007: 262), CIDs should be "challenged (...) by vast social inequalities and citizens' historical struggle for inclusive citizenship and the right to the city". She has indeed questioned their capacity to find a "stable ground" in South Africa under the current political and socio-economic conditions. Following up on this approach in terms of "stabilisation" and resilience, but based on more recent observation, we argue that in Cape Town and Johannesburg, CIDs governing structures quietly reshape CIDs to straddle the dual agenda of growth and development, through the crafting of contrasting local Third Ways. These strategies enable them to accommodate criticisms and ensure that CIDs remain disconnected from the broader denunciation of neoliberal policies.

\section{Local Third Ways}

In Cape Town, a charity-based agenda is being pushed forward by the growth coalition. It breaks away from the CTP's original and aggressive neoliberal agenda that stood in contradiction with developmental concerns and threatened the sustainability of the PPP. This shift followed the appointment, in 2003, by the newly elected ANC Mayor, of a charismatic political figure, A. Boraine $^{\mathrm{xiv}}$ at the head of the CTP. His reputation, achievements, and positioning helped refund and stabilize the PPP. The CTP Board was expanded to include socially-oriented organisations as well as prominent artists and academics, and had its agenda redrawn: while it used to "develop, manage and promote the CBD" (CTP 2003: 4), it now "[focuses] on (...) challenges which face homeless children, youth and adults" (CTP 2005: 6). It led to a late addition to the motto of the "World Class City for all" in the mid-2000s, an idea that was pursued by the DA when it returned to power. The CTP now seeks 
Didier S., Morange M., Peyroux E., 2013, “The Adaptative Nature of Neoliberalism at the Local Scale: Fifteen Years of City Improvement Districts in Cape Town and Johannesburg”, Antipode, 45(1), pp. 121-139.

to promote "an inclusive, productive and diverse City Centre" (CTP 2006: 1), in line with the 2009 Central City Development Strategy, which denounces the "urban imbalance and lack of integration", and with the Economic and Human Development strategy (City of Cape Town 2006: 16). To make the central city "a place for all" (CTP 2009: 1 and 40), the CTP "recognises the need to address the needs of the poor"xv". A "social development unit" created in 2006 within the CCID implements social programmes" and an "innovative labour intensive partnership" with faith-based NGOs that provide homeless and unemployed adults with piece-jobs - they supplement the existing street cleaning service in the CBD, a typical neoliberal "win-win" solution. The CCID thus claims that it "achieves both urban management and social development aims" (CCID 2007: 3), and that its approach is "people-centred".

However, the "caring arm" of the CTP (CTP 2009: 12) receives only 3\% of the CCID's annual budget, as opposed to $51 \%$ for security which, together with cleaning, accounts for $90 \%$ of the budget. True to the liberal tradition of charity and paternalism in Cape Town, Conservative Christian organisations are favoured as partners, as opposed to the political organisations and trade unions that mobilized against a project of municipal 'nuisance' bylaw in 2006. Moreover CCID security officers continue to patrol the streets of the CBD to forcibly remove homeless people to shelters, a controversial practice that even some CCID social workers ${ }^{\mathrm{xvi}}$ are uncomfortable with or critical about. The Cape Town case thus echoes Eick's analysis of BIDs in the USA and Germany, on the role of non-profit organisations and faith-based initiatives flanking a "repressive security strategy" with "pseudo-philanthropic services" (Eick 2009: 9). Following this role model, other CID boards have embraced similar "Third Way" tactics (in Sea Point and Woodstock for instance).

While charity-based conceptions prevail, the eviction of working-class and poor people from the city centre is considered an unavoidable market trend. World class loft-style developments are booming (Pirie 2007) while property prices have sky-rocketed. The CTP acknowledges "the rising property prices and pressures of displacement on poor communities" as well as the "lack of affordable housing for a range of income groups", but whatever its genuine desire to enhance social diversity, it contributes to fostering a property boom that narrows down land opportunities for social housing. These palliative measures do not challenge the core principles of CIDs and their alleged trickle-down effect goes unquestioned. "The Council's position on the tension between growth and poverty reduction is clear - that the size of the cake must be grown, whilst sharing the cake more equitably" (City of Cape Town 2006).

'Social' flanking programmes have also been introduced in certain CIDs in Johannesburg. For instance, the Rosebank Management Improvement District, working with the Rosebank Homeless Association, supports a car guard scheme employing homeless people. The CJP has established a street newspaper as part of a job creation strategy in co-operation with inner city church groups and the Johannesburg Trust for the Homeless. However, as opposed to Cape Town, these measures are not implemented by a centralised public private coalition - indeed the CJP managing most of the CIDs only represents the business sector - and they remain isolated.

A local form of "Third Way" has been promoted by "the Johannesburg Housing Company (JHC), a social housing company developing rental housing units for low to middle income households in the inner city. In 2004, the JHC set up the eKhaya Neighbourhood programme in the densely populated neighbourhood of Hillbrow, on an informal basis (the CID was legislated in 2009). According to the CID organiser, it is said to combine conventional CID management with social development, and puts the emphasis on "social contracts and building trust" in order for the residents to recover from the breakdown of "anonymity and isolation" (Adler 2008: 23). In addition to the Executive Committee of property owners, the scheme mobilises a network of caretakers, local businesses, community organisations, churches and city agencies. Besides cleaning and safety, social events for children and health- and safety-related campaigns are organised. These activities complement the "community development" department of the JHC, which provides support services to tenants (vocational training, financial management training, assistance and counselling) and supplements or replaces lacking public facilities (crèches, sports leagues and after-work programmes among others). 
The emphasis on social capital and social cohesion is in line with a dominant theme in the academic as well as practitioner literature, and in development discourses, particularly that of the World Bank, i.e. the correlation between associational activity and local economic growth (Sheppard and Leitner 2010). However, as stated by the CID organiser (Adler 2008: 23), the eKhaya CID primarily aims at supporting the housing companies' capital investments in the inner city: "Hillbrow property owners are using a hidden resource to support their capital investments into the inner city low-income residential market. They are recognising that social dynamics - conventionally suppressed and ignored - can be powerfully harnessed as a cornerstone in securing, consolidating and preparing their assets for growth".

Emblematically, the eKhaya Neighbourhood programme gained recognition in 2009: it won a SAPOA Award in the Social/Environmental Impact Developments Project Category as well as the JDA's Halala Joburg! Award: "Sustaining Joburg; past, present and future". Residential CIDs in the inner city are backed by public authorities. As stated in the 2007 Inner City Regeneration Charter (City of Johannesburg 2007), the City supports the concept in so called "stressed areas". In 2009, the eKhaya CID was awarded a grant funding from the City of Johannesburg to establish the CID formally. Support to residential CIDs is in line with a shift in urban policies and discourses driven by criticisms coming from the City, and articulated in the Inner City strategies, since 2005. However, no generic model has emerged yet: since residential CIDs are implemented by different stakeholders, variations exist in their alleged social inflexions. Moreover, these isolated cases do not mean that the City would altogether withdraw its support from business and commercial CIDs in the CBD. The City still collaborates on a number of CID activities, such as urban management and visible policing, and the JDA remains involved in sectorial clusters in the CBD. As stated by a city official as regards the Inner city regeneration Charter: "it has been a very balanced approach in terms of how you drive development without necessarily eroding the free market system" "xvii.

\section{CONCLUSION}

The analysis of neoliberalisation in South Africa, while shedding light on some of the experiments in the Global South, have broader implications for studies on neoliberalism. First, it highlights the importance of a fine-grained social and spatial analysis to gain a thorough understanding of the differentiation and variation in neoliberalisation processes both at local and sub-local levels.

Johannesburg and Cape Town share a number of similarities in terms of the adoption of neoliberal principles at metropolitan level. They face competing demands, i.e. the search for growth, competitiveness and redistribution, both encouraged by the central state and witness local forms of contestation that crystallize around the neoliberal reforms of public services delivery and the access of "previously disadvantaged populations" to public spaces. But as far as CID are concerned, they differ in their local and micro-local responses to these tensions. They produce distinct neoliberal paths that follow distinct timeframes and that are linked to historical dynamics, city and neighbourhoods specificities, as well as local agency, in particular the types of local coalitions. Neoliberalisation processes are indeed polymorphic and produce place, scale and territory-specific forms of governance (Brenner et al. 2010a). But they do not necessarily follow a linear "roll back-roll out" path. As illustrated by our case studies, they generate their own forms and dynamics of incremental change:

In Johannesburg, a polycentric metropolitan region with a large, populated and diversified inner city, a lesser degree of centralisation and control have left room for local private and community initiatives, whether legislated or not, and for a greater diversification of the CID model. A form of "Third Way" has emerged in predominantly Black residential neighbourhoods of the inner city that are affected by urgent needs in terms of housing and living conditions. The social inflexion of the CID model is driven by a private stakeholder, a housing company that has large assets in the inner city. Promoting social capital and trust among the communities, in particular between tenants and landlords, represents an attempt to support capital investment by allegedly addressing social development. This evolution has been supported by public policies in a context of political stability and continuity at local level, as well as of alignment of the ANC-led governments between central, provincial and local spheres. It has 
been in line with a gradual discursive shift towards more socially-oriented policies and a subsequent inflexion of a long term strategic and encompassing vision of the city's development that attempt to reconcile economic and social goals.

In Cape Town, a less polycentric metropolitan area with a smaller more affluent and less populated city centre, the implementation of CIDs was driven by a centralised structure of governance, dominated by the CTP, whose objectives were to respond to the needs of large companies, and to the international tourism industry in the CBD by fostering urban regeneration. It led to an early coherent and planned coverage of the CBD by CIDs, subsequently followed by a dualization of the model (security/LED oriented) when CIDs spread to the peripheries. The local "social turn" directly emerged from this centralised structure and led to a unified model that is gradually implemented on a pragmatic basis in many CIDs. It feeds on the local tradition of charity and relies on palliative measures of "workfare" rather than on social concerns over housing issues and racial debates. However, political instability and tensions within local governments have prevented the development of a more comprehensive vision of the city's future that would encompass CIDs. Current debates on the drafting of a metropolitan CDS and an Economic Development Agency (inspired from the JDA) could draw toward a Johannesburg's scenario.

Second, while urban and regional political economy demonstrates that neoliberalisation is neither coherent, nor comprehensive or unchallenged (Brenner and Theodore 2002a; Larner 2003; Leitner et al. 2007; Brenner et al. 2010), the South African case has proven enlightening to decipher the resilience of neoliberalisation, as an adaptive process to local political constraints and complex interplay of political visions and practices. It offers interesting avenues of thoughts to enhance our theorization of variegation as a local process of internalization of contestation. Changes have been incremental in both cities, but not transformative. These processes provide the basis for consolidation and further development of neoliberalisation. Despite discursive re-orientations towards more socially inclusive forms of development, CIDs remain deeply entrenched in private strategies linked to market primacy and business-friendly policies. The crafting of "local Third Ways" has enhanced their sustainability, even if such stabilization is temporary. After all, instability is part and parcel of neoliberalisation as a process and "perturbations and experiments are the process" itself (Brenner et al. 2010: 210).

Third, unpacking "local Third Ways"" rhetoric might also help to strengthen the awareness of those combating neoliberalism, in particular social movements: this approach enables to see how discourses adopt new political guises while pursuing a similar agenda (see also Peyroux forthcoming). This awareness can prompt a better political reactivity to the local variations of neoliberalism and contribute to connect CID criticisms and broader mass protest against neoliberalisation in South Africa.

To connect CIDs, neoliberalisation and post-apartheid debates finally proved useful to assess the transferability of exogenous models to the global South where poverty issues, inequalities and developmental concerns are at the core of the political debate: some scholars question the relevance of an analysis through the neoliberal lens (Parnell and Robinson: forthcoming), calling for a refocusing on developmental issues and pro-poor policies that in their eyes better fit the specificities of the South African context. We acknowledge the legitimate criticisms concerning the adoption of a simplistic translation of a neoliberal analytical framework originally devised in (and for) cities of the North. However, we believe that resorting to such a framework has also improved our understanding of the role of the global South in the evolution of the neoliberal paradigm, moving beyond a top-down / North-South conception of the diffusion of neoliberal value and practices and that it is a fruitful avenue of research. Calling for more comparative, multi-scalar and transnational accounts of neoliberalisation crossing the North-South divide will certainly bring forth enormous methodological and theoretical challenges. How researchers overcome these in the future remains an open question.

\section{References}


Adler J (2008) eKhaya - The anatomy of an inner city residential neighborhood. Trafalgar Inner City Report: 23-25

Ballard R, Habib A and Valodia I (2006) Voices of protest: social movements in post-apartheid South Africa. Pietermaritzburg: University of KwaZulu-Natal Press

Beall J, Crankshaw O and Parnell S (eds) (2002) Uniting a Divided City. Governance and social exclusion in Johannesburg. London: Earthscan

Beavon K (2004) Johannesburg. The making of the City. Pretoria: University of South Africa Press

Bénit-Gbaffou C, Didier S and Morange M (2008) Communities, the Private Sector, and the State: Contested Forms of Security Governance in Cape Town and Johannesburg. Urban Affairs Review 43: 691-717

Bénit-Gbaffou C, Fabiyi S and Peyroux E (eds) (2009) Sécurisation des quartiers et gouvernance locale. Enjeux et défis pour les villes africaines. Paris: IFAS-Karthala

Berg J (2004) Private policing in South Africa: the Cape Town City Improvement District pluralisation in practice, Society in Transition 35(2): 224-250

Bond P. (2006) Reconciliation and economic reaction: Flaws in South Africa's elite transition. Journal of International Affairs, 60(1), 141-156

Boraine A (2009) Public-private partnerships and urban regeneration in the central city. Lessons from the first 10 years of the Cape Town Partnership. International Downtown Association 55the Annual conference, Milwaukee, September 11-15)

Bek, D., Binns, J.A. and Nel, E.L. (2004) 'Catching the development train'; Perspectives on 'topdown' and 'bottom-up' development in post-apartheid South Africa. Progress in Development Studies, $4,1,22-46$

Bremner L (2000) Reinventing the Johannesburg inner city. Cities 17 (3): 184-193

Brenner N and Theodore N (2002a) Cities and the geographies of 'actually existing neoliberalism'. Antipode 34(3): 349-379

Brenner N and Theodore N (eds) (2002b) Spaces of neoliberalism. Urban restructuring in North America and Western Europe. Oxford: Blackwell Publishing

Brenner N, Peck J and Theodore N (2010a) Variegated neoliberalization: geographie, modalities, pathways. Global Networks 10(2): 182-222

Brenner N, Peck J and Theodore N (2010b) After Neoliberalization? Globalizations 7 (3): 327 - 345

Cameron R (2000) Megacities in South Africa: a solution for the new millenium? Public Administration and Development 20: 155-165

Cape Town Partnership (CTP) annual reports 2003, 2005, 2006, 2007, 2008 and 2009

CCID (2007) Annual Report

City of Cape Town (1989) Study of Cape Town CBD offices. Summary report on consultant's findings. City Engineer's Department, Cape Town Planning Branch, Report n¹5/1989

City of Cape Town (2001) Toward an economic development strategy for the City of Cape Town. A discussion paper, mars 2001

City of Cape Town (2006) Economic and Human Development Strategy. Cape Town: EHD Directorate

City of Cape Town (2005) Integrated Development Plan 2006/7

City of Cape Town (2009) Spatial Development Framework. Technical Report (first draft) 
Didier S., Morange M., Peyroux E., 2013, “The Adaptative Nature of Neoliberalism at the Local Scale: Fifteen Years of City Improvement Districts in Cape Town and Johannesburg”, Antipode, 45(1), pp. 121-139.

City of Johannesburg (2004) Johannesburg Inner City Regeneration Strategy and Business Plan 2004 $-2007$

City of Johannesburg (2005) Human Development Strategy. Joburg's commitment to the poor: Office of the City Manager, Corporate Planning Unit

City of Johannesburg (2007) Inner City Regeneration Charter, Johannesburg: City of Johannesburg

COHRE (2005) Any room for the poor? Forced Evictions in Johannesburg, South Africa: Centre on Housing Rights and Evictions

Cook I R (2008) Mobilising Urban Policies: The Policy Transfer of US Business Improvement Districts to England and Wales. Urban Studies, 45 (4): 773 - 795

de Beus J and Koelble T (2001) The Third Way diffusion of social democracy: Western Europe and South Africa compared. Polikon. South African Journal of Political Studies, 28 (2) 181 - 194

Didier S, Peyroux E and Morange M (2009) La diffusion du modèle du City Improvement District (CID) à Johannesburg et au Cap. In C Bénit-Gbaffou, S Fabiyi and E Peyroux (eds) op. cit. (pp.85112). Paris: IFAS-Karthala

Dubresson A (2008) Urbanisme entrepreneurial, pouvoir et aménagement, Les CID au Cap. In A Dubresson and S Jaglin (eds) Le Cap après l'apartheid, Gouvernance métropolitaine et changement urbain (pp.183-215). Paris: Karthala

du Toit C (2006) Accelerated and shared growth initiative for South Africa (ASGI-SA). An Integrated National Strategy for Social Development

Eick V (2008) Raumgreifender Neoliberalismus. Kriminalpolitik und Privatisierung öffentlicher Räume. In Lange H-J (ed) Kriminalpolitik (pp. 361- 385). Wiesbaden: VS Verlag

Eick V (2009) Security semi-states and the governance of the punitive city: BIDs, a new instrument for containment and exclusion. Paper presented at the 5th international conference of the research network Private Urban Governance \& Gated Communities. Santiago de Chile

Emery A (2006) Privatization, neoliberal development, and the struggle for workers' rights in postapartheid South Africa. Social Justice 33 (3): 6-19

Fine B, Ashman S and Newman S (2010) The Developmental State and Post-Liberation South Africa. in Neeta, Misra-Dexter and Judith Testing Democracy: Which Way Is South Africa Going? (pp. 2345), Cape Town: ABC Press / Institute for a Democratic South Africa

Forest R (2001) Social cohesion, social capital and the neighborhood. Urban Studies 38 (12): 21252143.

Fuller C and Geddes M (2008) Urban governance under neoliberalism: New Labour and the restructuring of state-space. Antipode 40(2): 252-282

Giddens A (2000) The Third Way and Its Critics. Cambridge: Polity

Green-Pedersen C, van Kersbergen K and Hemerijck A (2001) Neo-liberalism, the 'Third Way' or What? Recent Social Democratic Welfare Policies in Denmark and the Netherlands. Journal of European Public Policy 8(2): 307-325

Guillaume P (2001) Johannesburg. Géographies de l'exclusion. Paris: IFAS-Karthala

Harvey D (1989) From Managerialism to Entrepreneurialism: The Transformation in Urban Governance in Late Capitalism. Geografiska Annaler B 71: 3-17

Hoyt L (2006) Importing ideas: The transnational transfer of urban revitalisation policy. International Journal of Public Administration 29: 221-243.

Larner W (2003), Neoliberalism?. Environment and Planning D 21: 509-512 
Didier S., Morange M., Peyroux E., 2013, “The Adaptative Nature of Neoliberalism at the Local Scale: Fifteen Years of City Improvement Districts in Cape Town and Johannesburg", Antipode, 45(1), pp. 121-139.

Le Fleur CC (2005) The levels and patterns of racial residential desegregation in Cape Town. $\mathrm{PhD}$ thesis, University of Cape Town

Leitner H Sheppard ES Sziarto K and Maringanti A (2007) Contesting urban futures: decentering neoliberalism. In H Leitner, J Peck ES Sheppard (eds) Contesting neoliberalism: Urban frontiers (pp.1-26). New York and London: The Guilford Press

Lipietz B (2008) Building a Vision for the Post-Apartheid City: What Role for Participation in Johannesburg's City Development Strategy? International Journal of Urban and Regional Research 32 (1): $135-63$

Lippert R (2009) "Signs of the Surveillant Assemblage: Privacy Regulation, Urban CCTV and Governmentality" Social and Legal Studies: An International Journal. 18(4): 505-522.

Mabin A (2007) Johannesburg: (South) Africa's aspirant global city. In K Segbers, S Raiser and K Volkmann (eds) The Making of Global City Regions. Johannesburg, Mumbai/Bombay, São Paulo, and Shanghai: The Johns Hopkins University Press.

McCann E and Ward K (2010) Relationality/territoriality: Toward a conceptualization of cities in the world. Geoforum 41(2): 175-184

McDonald DA and Smith L (2004) Privatising Cape Town: from apartheid to neo-liberalism in the mother city. Urban Studies 41(8): 1461-1484

McDonald DA (2008) World city syndrome: neoliberalism and inequality in Cape Town. New York: Routledge

Marais H (2001) South Africa: Limits to Change. The political economy of transition (revised and expanded new edition). Zed Books:

Marquardt N, Füller H (2008) Die Sicherstellung von Urbanität. Ambivalente Effekte von BID auf soziale Kontrolle in Los Angeles. In: Pütz R (ed) Business Improvement Districts. Passau: 119-138.

Michie V. and Padayachee J. (2001) South Africa: A Third Way in the Third World? In Arestis, P. and Sawyer, M (eds) The Economics of the Third Way (pp. 183-200) London: Edward Elgar.

Miraftab F (2004) Neoliberalism and casualisation of public sector services: the case of waste collection services in Cape Town. International Journal of Urban and Regional Research 28(4): 874892

Miraftab F (2007), Governing Post-apartheid Spatiality: Implementing City Improvement Districts in Cape Town. Antipode 39(4): 602-626

Mitchell D (2003) The Right to the City: Social Justice and the Fight for Public Space. New York and London: Guilford Press.

Morange M and Didier S (2008) Gouvernance sécuritaire dans les quartiers riches du Cap 1995-2006 : vers la «normalisation post-apartheid». Une lecture en termes de temporalités et d'échelles. In A Dubresson and S Jaglin (eds), op. cit. (pp.217-249). Paris: Karthala

Morange M and Didier S (2009) Le Cap: délégation publique en transition (1995-2008). Construction de partenariats sécuritaires et réévaluation du localisme. In Bénit-Gbaffou C, Fabiyi S, Peyroux E (eds) (2009) op. cit. (pp.355-389). Paris : IFAS-Karthala

Morçöl G and Zimmermann U (2006) Metropolitan governance and business improvement districts. International Journal of Public Administration 29(1-3): 5-29

Morris A (1999) Bleakness and light: inner-city transition in Hillbrow Johannesburg. Johannesburg: Witwatersrand University Press

Murray M (2008) Taming the disorderly city: the spatial landscape of Johannesburg after apartheid. Cape Town: University of Cape Town Press. 
Narsiah S (2010) The neoliberalisation of the local state in Durban, South Africa. Antipode 42 (2): $374-403$

Nell E and Binns T (2001) Initiating 'Developmental Local Government' in South Africa: Evolving Local Economic Development Policy. Regional Studies: The Journal of the Regional Studies Association 35(4): 355-362

OECD (2009) The Strategies for urban competitiveness and governance: the case of Cape TownAssessment and Recommendations. Paris: OECD

Oldfield S and Stokke K (2007) Political polemics and local practices of community organization and neoliberal politics in South Africa. In H Leitner, J Peck and ES Sheppard (eds) Contesting neoliberalism: Urban frontiers (pp.139-156). New York and London: The Guilford Press

Parnell S and Pieterse E (1999) Developmental Local Government: The second wave of post-apartheid urban reconstruction. Africanus 29(2): 68-85

Parnell S and Pieterse E (2002) Developmental Local Government. In S Parnell, E Pieterse, M Swilling and D Woolridge (eds) Democratising Local Government. The South African experiment (pp.79-91). Cape Town: UCT Press

Parnell S and Robinson J (2006) Development and urban policy: Johannesburg's City development strategy. Urban Studies 43(2): 337-355

Parnell S and Robinson J (2010) (Re)theorising cities from the global south: looking beyond neoliberalism, forthcoming

Parnell S, Pieterse E, Swilling M and Wooldridge D (eds) (2002) Democratising local government. The South African experiment. Cape Town: UCT Press

Peck J and Tickell A (2002) Neoliberalizing space. Antipode 34(3): 388-392

Peet R (2002) Ideology, discourses and the geography of hegemony: from socialist to neoliberal development in postapartheid South Africa. Antipode 34(1): 54-84

Peyroux E Legitimating Business Improvement Districts in Johannesburg: A discursive perspective on urban regeneration and policy transfer, European Urban and Regional Studies, theme issue on BIDs, forthcoming.

Peyroux E (2008) City Improvement Districts in Johannesburg: An examination of the local variations of the BID model. In $\mathrm{R}$ Pütz (ed.) Business Improvement Districts. Passau, Geographische Handelsforschung 14: 139-162

Pieterse E (2002) From divided to integrated city? Critical overview of the emerging metropolitan governance system in Cape Town. Urban Forum 13(1): 3-37

Pieterse E (2003) Tracing the 'integration' thread in the South African urban development policy tapestry. Urban Forum 18(1): 1-30.

Pieterse E (2004) Untangling 'integration' in urban development policy. Urban Forum 15(1): 1-35

Pirie G (2007) Reanimating a Comatose Goddess': Reconfiguring Central Cape Town. Urban Forum 28(3): $125-151$

Plancq-Tournadre M (2006), Gestion durable de l'eau au Cap (Afrique du Sud). Retour sur la difficile conciliation des durabilités environnementale, financière et sociale (2001-2004), Cybergéo paper 348, 20 September 2006 (http://www.cybergeo.eu/)

Popke, E J and Ballard, R (2004) Dislocating Modernity: Identity, Space and Representations of Street Trade in Durban, South Africa, Geoforum, 35: 99-110.

Rogerson CM (1996) The private sector and local economic development in South Africa, GeoJournal (39): 97-104 
Rogerson CM (2003) Towards Pro-Poor local economic development: The case for sectoral targeting in South Africa. Urban Forum 14 (1): 53-79

Rogerson CM (2004) Towards the World-Class African City- Planning local economic development in Johannesburg. Africa Insight 34 (3): 12-21

Roumet R (2010) Partager la fonction répressive : la collaboration entre la police et une compagnie de sécurité privée dans un quartier aisé du Cap, EchoGéo 13, URL : http://echogeo.revues.org/11927

Seeking J and Nattras N (2005) Class, Race and Inequality in South Africa. Pietermaritzburg: University of KwaZulu-Natal Press

Smith L (2004) The murky waters of the second wave of neoliberalism: Corporatisation as a service delivery model in Cape Town. Geoforum 35: 375-393

SSA (2001) Population Census. Pretoria: Statistics South Africa

Tomlinson R (1999) From exclusion to inclusion: rethinking Johannesburg's central city. Environment and Planning A, 31(9): 1655-1678

Töpfer E., Eick V. and J. Sambale (2007) 'Business Improvement Districts. New Instrument for Containment and Exclusion. Lessons from North America and Britain. PROKLA 149, 37(4): 511-528

Van Donk M, Swilling M, Pieterse E and Parnell S (2008) Consolidating Developmental Local Government: Lessons from the South African experience. Cape Town: UCT Press

Ward K (2006) 'Policies in motion', urban management and state restructuring: the trans-local expansion of Business Improvement Districts. International of Urban and Regional Research 30(1): $54-75$

Wolf J F (2006) Urban Governance and Business Improvement Districts: The Washington, DC

BIDs. International Journal of Public Administration 29 (1): 53-75

\footnotetext{
${ }^{\mathrm{i}}$ Scholars have focused on macro-economic policies, the reforms of municipal services (Mac Donald and Smith 2004; Smith 2004; Miraftab 2004; Bond and McInnes 2007; Narsiah 2010), Local Economic Development (Rogerson 2003; Pieterse 2004), spatial development strategies (Bek et al. 2004), City Development Strategies (Parnell and Robinson 2006) and inner city policies (Bremner 2000).

ii The CCID's board is made of representatives of the local and international property market, e.g. Theodore Yach Property Services, one of the founding directors of the CTP and Eurocape an Irish development and investment company that claims it has invested around R1 billion in the Cape Town CBD (http://www.joburg.org.za/content/view/3453/253/).

iii It aimed at alleviating poverty, linking reconstruction with the right to basic services and development.

${ }^{\text {iv }}$ I.e. orthodox fiscal policy, open markets, trade liberalization, privatization and a pro-investment environment.

$\checkmark$ Drawing from the experience of industrialised states of Asia where state drives development, the "developmental state" promotes direct state interventions in various areas (training, economic and social development, capacity building) (Beall et al. 2002; Parnell and Pieterse 1999, 2002; Nell and Binns 2001; van Donk et al. 2008).
} 


\footnotetext{
vi The creation of single metropolitan authorities (Unicities) in 2000 occurred through the "amalgamation" of previously racially-based municipalities. Local governments in South Africa were recognized as an autonomous sphere of authority by the legislation and are theoretically largely self-financed.

vii According to A. Boraine, former City Manager and current head of the Cape Town Partnership (http://www.andrewboraine.com/2010/05/). At both city and provincial levels, the DA has been challenging the power of the ANC since the first local elections in 1996, a unique situation in South Africa.

viii City Improvement District Act $\mathrm{n}^{\circ} 12$ of 1997 (Provincial Government, Gauteng) and Municipal bylaw for the establishment of CID, Provincial Gazette 6118, 26 March 2004 (City of Cape Town). According to these documents, in both cities, CIDs are established as non-profit organizations for a period of 3 years, but they must be renewed in Cape Town, whereas in Johannesburg, a CID can continue to exist as long as no changes to the business plan are made, except for the newly established Residential CIDs. In both cases, to set up a CID it is required to secure more than $50 \%$ of formal agreement from all the property owners concerned or more than 75\% for residential CIDs. When the CID is legislated the levy becomes compulsory for all property owners CIDs. This levy cannot be spent outside of the CID perimeter.

${ }^{\text {ix }}$ In residential CIDs, the required proportion of landowners supporting the creation of a CID should be increased to $75 \%$ (instead of the current minimum of 51\%); the approval must be for a period of three years only; and they must provide a detailed breakdown of their budget.

x Municipal Special Rating Areas System Governed by Section 22 of the Municipal Property Rates Act and the Municipal Finance Management Act.

xi Gael Reagon, Cape Argus, 4 December 2006.

xii Collective email released by the South African National Traders' Alliance, 7 June 2007.

xiii Under apartheid informal street trade was not allowed in « European spaces » and was confined to " African spaces » and tourist markets (Popke and Ballard 2004: 104).

xiv Former City Manager (1997-2001), former Special Advisor to the Minister for Provincial and Local Government (2001-2003) and Deputy Director-General in the Department of Constitutional Development where he helped to draft the local government chapter in the Constitution and the 1998 White Paper on Local Government and to set up the South African Cities network. Also a former apartheid opponent and United Democratic Front member, related to the judge Boraine who chaired the Truth and Reconciliation Commission.

xv (http://www.capetownpartnership.co.za/).

xvi Interviews with social workers of the CCID (2008 and 2009).

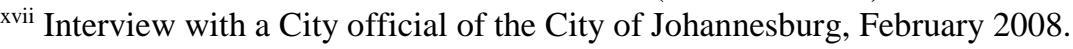

